\title{
A Comparative Study of FDPs and D-dimers in Patients with Breast Cancer
}

\author{
M Z KHAN M TAYYIB T TASNEEM M FAROOQ I D UJJAN N A CHAUDHRY \\ Department of Pathology: Postgraduate Medical Institute, Lahore. \\ Correspondence to Dr. Malik Zeb Khan. Demonstrator Pathology, Khyber Teaching Hospital, Peshawar
}

\begin{abstract}
Seventy Five subjects were selected. Fifty subjects were breast cancer patients and 25 healthy control subjects were included. FDPs and D-dimers were performed by using commercially available kits. Results obtained were analyzed by using chi-square $\left(\mathrm{X}^{2}\right)$ test and level of significance was done. A significant increase in the levels of FDPs and Ddimers were found in patients with breast cancer.
\end{abstract}

Key words: Breast cancer, FDPs, D- dimers

Plasma D-dimers are the specific derivatives of crosslinked fibrin, which are produced when fibrin is degraded by plasmin and concentrations are raised by thrombolysis . Plasma D-dimer represents a significant advance over current and historical FDP assays. Firstly it identifies specifically, the presence of cross-linked fibrin derivatives without interference from fibrinogen and non-cross-linked fibrin, and therefore, identifies intravascular thrombosis and fibrinolysis as distinct from fibrinogenolysis. Because of high specificity of D-dimer, the monoclonal antibody can be used with plasma samples, thereby differentiating fibrinolysis from fibrinogenolysis and conferring an advantage over most standard assays for FDP ${ }^{2,1}$. D-dimer is the only test that directly a ddresses both thrombin and plasmin generation i.e. generation of thrombin resulting in a cross-linked fibrin clot and of plasmin resulting in a lysis of a cross-linked fibrin $\mathrm{clot}^{3}$. The use of a rapid and sensitive D-dimer test for diagnosis and during the treatment of disseminated intravascular coagulation (DIC) and thrombolytic therapy, may give a better understanding of the formation and dissolution of fibrin in thrombotic disease $^{4}$. Detection of fragment DD, therefore offers a unique adyantage over other laboratory tests for DIC, because it addresses both dimensions of DIC ${ }^{3,5.6}$.

The D-dimer and FDP tests are very useful for the rapid diagnosis of $\mathrm{DIC}^{7}$. Clinically, the relationship between malignancy and thrombosis has been obvious for over 100 years. Thrombo-embolism is present in up to half of cancer patients at autopsy and there is higher incidence of occult malignancy in patients with deep vein thrombosis (DVT). Thrombosis in cancer often is migratory and may involve superficial veins and relatively unusual sites. In the laboratory, evidence of intravascular coagulation is readily obtained. Some have thrombocytopenia, falling fibrinogen levels and raised fibrinogen degradation product (FDP), but these represent only the decompensated form of DIC, and a larger proportion has evidence of compensated or overcompensated DIC. Thrombocytosis is more common, and functional defects such as reduced adhesion, aggregation and clot retraction also may be observed ${ }^{8}$.
Hyperfibrinogenemia is common but acquired dysfibrinogenemia is rare unless the liver is involved. As intravascular activation of coagulation and fibrinolysis occurs 'together, cancer patients may have shortened euglobulin c lot 1 ysis t imes, d ecreased p lasminogen levels and an increase in plasmin-antiplasmin complexes. Most. patients with cancer complicated by acute DIC have elevated FDP levels. The likelihood of increased FDP is greater in patients with remote metastases, compared to localized disease and may have prognostic value.

The purpose of the present study is to assess the coagulation abnormalities in patients of breast cancer and to help the clinician in early detection of DIC and management of patients at different stages of breast cancer.

\section{Subjects and Methods}

Seventy five subjects were selected and divided into two groups. Group I included 50 breast cancer patients and Group II included 25 normal, healthy controls: $1.8 \mathrm{ml}$ of blood was mixed with $0.2 \mathrm{ml}$ of sodium citrate for fibrinogen and D-dimers. $2 \mathrm{ml}$ of blood was transferred to FDP collection tube for FDPs estimation. The results and data obtained were subjected to statistical analysis by using chi-square test $\left(\mathrm{X}^{2}\right)$ and level of significance was done.

\section{Results:}

The results and level of significance of these groups are given in tables 1 and 2

Table 1: FDPS in Control Group (II) \& Breast Cancer Patients (I)

\begin{tabular}{lll}
\hline FDPS $\mu \mathrm{g} / \mathrm{ml} l$ & $\begin{array}{l}\text { Group-I } \\
\text { Breast Cancer Patients }\end{array}$ & $\begin{array}{l}\text { Group-II } \\
\text { (Control) }\end{array}$ \\
\hline$<5$ & $07(14 \%)$ & 25 \\
$>5<40$ & $15(30 \%)$ & - \\
$\geq 40$ & $28(56 \%)$ & - \\
Total & 50 & 25 \\
\hline
\end{tabular}

Statistical analysis: II Vs I $\mathrm{P}<0.01(\mathrm{HS})$ 
Table 2: D-dimers in Control Group (II) and subjects with Breast Cancer (I)

\begin{tabular}{lll}
\hline $\begin{array}{l}\text { D-dimer } \\
(\mathrm{ng} / \mathrm{ml})\end{array}$ & $\begin{array}{l}\text { Group I } \\
\text { (Subjects with ca breast) }\end{array}$ & $\begin{array}{l}\text { Group II } \\
\text { (Control) }\end{array}$ \\
\hline$<250$ & $01(02 \%)$ & 25 \\
$250-500$ & $29(58 \%)$ & - \\
$500-1000$ & $12(24 \%)$ & - \\
$1000-2000$ & $08(16 \%)$ & - \\
Total Subjects & 50 & 25 \\
\hline \multicolumn{2}{l}{ Statistical Analysis Il Vs I P $<0.01$} & (Highly significant)
\end{tabular}

\section{Discussion:}

Fibrinogen Degradation Products (FDPs): FDPs were found to be significantly increased $(p<0.01)$ in patients of breast cancer when compared with control group. These findings are consistent with the results of many investigators, including Gordon et al (1975) ${ }^{12}$, Francis et al $1994^{9}$ and Falanga \& Rickles (1999) ${ }^{5}$.

D-dimers: D-dimers were found to be significantly increased $(\mathrm{p}<0.01)$ in patients with breast cancer when compared with controls. These findings are consistent with the results of Falanga \& Rickles (1999) ${ }^{5}$ Gordon et al $(1975)^{10}$ and Rickles et al $(1992)^{8}$

\section{References:}

1. Levi $\mathrm{M}, \mathrm{Ten} \mathrm{CH}$. Disseminated intravascular coagulation. $\mathrm{N}$ Engl J Med 1999; 341 (8): 586-92.
2. Devine D V, G reenberg C S. M onoclonal a ntibody to fibrin D-dimer (DD-3B6) recognizes an epitope on the Y Chain of fragment D. Am J Clin Pathol 1988; 89: 663-66.

3. Carr JA, Mckinney M, McDonagh. Diagnosis of disseminated intravascular coagulation. Role of D-dimer. Am J clin Pathol 1989; 91:280-87.

4. Lane DA, Preston FE, Van Ross ME, Kakkar VV. Characterization of serum fibrinogen and fibrin fragments produced during DIC. Br J Haematol 1978; 40: 609-615.

5. Falanga A, Rickles FR. Pathophysiology of the thrombophilic state in the cancer patient. Semin Thromb Hemost. 1999; 25(2): 173-82.

6. Machin SJ. Acquired disorders of haemostasis. In Hoffbrand AV, Lewis SM (eds). Postgraduate Haematology $3^{\text {rd }}$ ed. London. Heinmann profession publishing 1991; 655-671.

7. Yu-M, Nadrella-A, Pechet-L. Screening test of disseminated intravascular coagulation: guidline for rapid \& specific laboratory diagnosis. Crit-Care-Med 2000; 28(6): 1777-80.

8. Rickles FR, Levine M, Edwards RL. Hemostatic alteration in cancer patients. cancer metastasis Rev. 1992; 11: 237.

9. Francis $\mathrm{CW}$, Marder VJ. Correlation of myocardial reperfusion after fibrinolytic therapy with detection of fibrin-specific derivatives in serum by application of an electrophoretic assay. Thromb Haemost 1985; 54:974.

10. Gordon LI, Kwaan HC. Thrombotic microangiopathy manifesting as thrombotic thrombocytopenic purpura/ hemolytic uremic syndrome in the cancer patient. Semin Thromb Hemost. 1999; 25(2): 217-21. 